\title{
The Importance of Intercultural Communication to improve Students' Global Leadership Competence: a Phenomenological Approach of Higher Education Institutions in Jakarta
}

\author{
Dr. Ir. Panji Hendrarso, M.M \\ STIAMI-Institute of Social Sciences and Management \\ Indonesia
}

\begin{abstract}
Aabstract
Nowadays, organizations, companies, and other institutions need leaders who are capable of moving in and through divergent cultural environments. An increasing number of studies in recent years have examined issues related to intercultural communication competence which is important for leaders in global era. Unfortunately, there are still a lot of college students who do not have such competence that will lead to failing to be global leaders. This study aims at answering the questions why university students in Jakarta are still lack of intercultural communication competence and how to improve students' competence in creating global leaders.This study employed a phenomenological approach of a qualitative research design. In this study a semi-structured interview is used to understand how participants experienced the phenomenon. Data were gathered from a total of 17 participants, consists of university students, leaders of student organizations, university graduates who have been working in public and private sector, and an official of the Ministry of Research, Technology and Higher Education was interviewed to get the perspectives on the ideal 21st century leaders and what the universities should do to achieve it.The research proved that intercultural communication plays a significant role in improving leadership competence in the global era. Further analysis indicated that there were differences between students who are competent in intercultural communication and those who are not which can be seen from various aspects. This study provides insights on the importance of intercultural communication competence for university students to be global leaders, discusses the advantages and disadvantages of having and not having inter-cultural communication competencies in the global era and offers recommendations for future research.
\end{abstract}

Keywords -Intercultural communication competence, global leadership,

\section{Introduction}

In organizational settings, intercultural communication competence has been a profound increase within businesses across the globe. In today's world, many business meetings occur among managers from different cultures around the world. They make deals, settlements and business offers without having to see each other or know each other. This advantage comes from our technological resources that allow us to travel, connect with each other through technological communication no matter where we are in the world. In recent years, many services such as education, hospitality, banks and investment agencies have become more and more globally oriented (Alnashi, 2012).

Intercultural communication competence requires the ability and understanding to cross-culturally adjust, task effectiveness within overseas assignments and maintaining healthy cultural relationships with individuals from different cultures (Miller, 2006, p.102).The challenge of creating and carrying out business propositions and solutions with people from the same country is already difficult enough, now, imagine the challenge to work and deal with people from another culture (Mohsin, 2006).

The literature recognizes the crucial role of leadership in the multicultural environment of global business (House et al. 2004; Karpin 1995; Sinclair \& Wilson 2002). It also argues that new skills are required from today's leaders working in the global economy, because leadership itself became more multicultural (Sinclair \& Wilson 2002) and it could be now defined as 'influence across national and cultural boundaries' (Mobley \& Dorfman 2003: xiii). Further, it was argued that leadership was 'enacted through communication' (Barge 1994: 21)and communication competence was a prerequisite for effective leadership (Flauto,1999).Addressing the existing problems and building on the suggestions of a relationship between communication competence and leadership (Flauto 1999; Rouhiainen 2005) as well as on the argument that in the global environment, communication competence should be intercultural (Chen 2005; Chen \& Starosta 1996; Samovar \& Porter 2004; Samovar et al. 2007). One of the major organizations that create leaders of a country is a higher education institution. 
However, until now there are still many leaders who graduated from universities do not have intercultural communication competence whereas a big country like Indonesia with more than 700 ethnics, 300 local languages and more than 7 religions and beliefs requires leaders who can bridge the differences. In globalization era, the need for leaders with global perspective and intercultural competence is demanded to meet these growing challenges and opportunities. In line with this, this study aims at answering the questions whether university studentsare able to apply intercultural communication and how to improvestudents' intercultural competence to gain global leadership skills.

\section{Literature Review}

As is known, the world is becoming nowadays a global village, in the sense that the technological achievements of this modern time have brought people closer together. This also means that people from different parts of the world and with different cultural backgrounds are working and communicating together (Kawar, 2012). To be effective in another culture, people must be interested in other cultures, be sensitive enough to notice cultural differences, and then also be willing to modify their behavior as an indication of respect for the people of other cultures (Bhawuk and Brislin, 1992). We have established that communication is a critical competitive advantage for businesses. For instance, effective communication enables a company to explain more succinctly to the customers the differences and superiority of the company's products and services in comparison to their competitors (Hilton, 2007). Employees in firms come from various walks of life and different cultures thus resulting in different personalities.

\section{Cultural Intelligence (CQ)}

CQ is a person's ability to function skillfully in a cultural context different than one's own (Earley \& Ang, 2003; Ng et al., 2009a, 2009b).Van Dyne has identified four factors of CQ which include CQ strategy, knowledge, motivation, and behavior. CQ strategy involves how a person acquires and then uses knowledge of other cultures-which includes contemplating assumptions, deciphering actions, and adjusting perspectives about the situation. CQ knowledge means that a person knows what she knows, but also knows what she doesn't know. Knowledge includes understanding about specific norms and behaviors, worldviews, values; and even historical, political, and governmental aspects of people and their culture. CQ motivation is a person's interest in engagement with people and the culture itself-the CQ motivated person enjoys learning and applying what she has learned with interest and confidence-she is comfortable with herself and with the ambiguity that comes when crossing cultures. CQ behavior is the person's ability to engage with others through language and nonverbal behavior that is developed through trial and error. In essence, the culturally intelligent person is highly motivated and interested in interacting with people from other cultures and is successfully able to assess a situation, scan for cues, and then act accordingly-this is also known as the concept of "mindfulness."(Van Dyne et al. cited in Ng et al., 2009a, 2009b).

Whereas the CQ framework based on Sternberg and Detterman (1986) integration of the various loci of intelligence is residing within the person. According to Sternberg and Detterman, metacognition, cognition, and motivation are mental capabilities that reside within the head, whereas overt actions are behavioral capabilities. Metacognitive intelligence refers to control of cognition: the processes individuals use to acquire and understand knowledge. Cognitive intelligence refers to knowledge structures and is consistent with Ackerman's (1996)intelligence-as-knowledge concept, which argues for the importance of knowledge as part of intellect. Motivational intelligence refers to the mental capacity to direct and sustain energy on a particular task or situation and recognize that motivational capabilities are critical to realworld problem-solving (Ceci, 1996). Behavioral intelligence refers to outward manifestations or overt actions: what a person does rather than what he or she thinks (Sternberg \& Detterman, 1986). Earley and Ang (2003) conceptualized a multifactor concept of CQ that includes mental (meta-cognitive and cognitive), motivational, and behavioral components. Those with high metacognitive CQ are consciously aware of the cultural preferences and norms of different societies prior to and during interactionsas seen in the following figure. 


\section{Figure 1Multifactor concept of Cultural Intelligence}

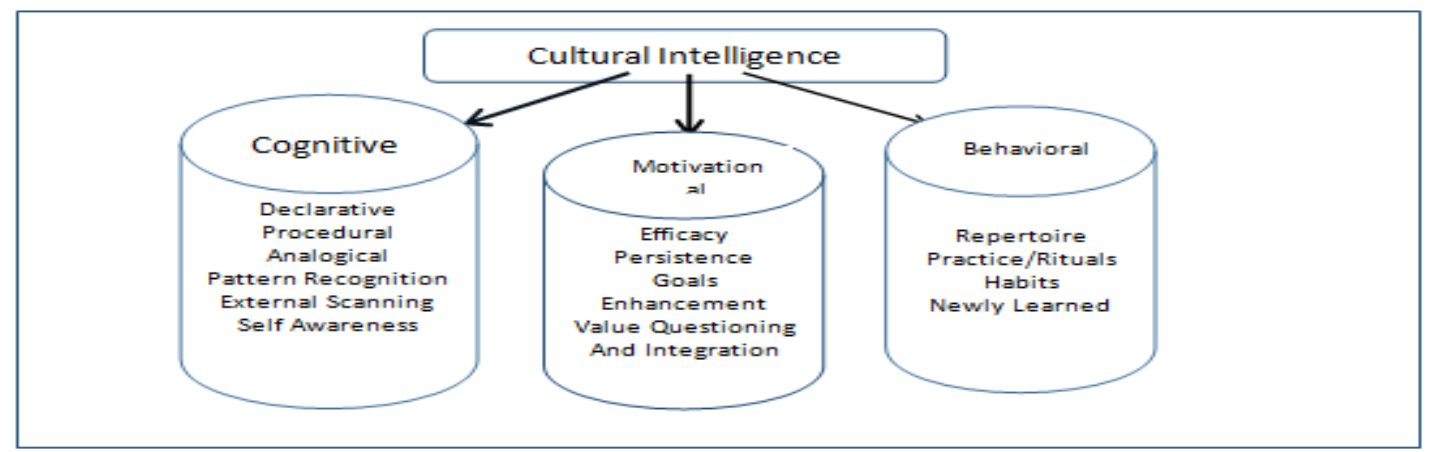

Source : Earley\& Ang (2003)

The cognitive factor of CQ refers to an individual's level of cultural knowledge or knowledge of the cultural environment. Cultural knowledge includes knowledge of oneself as embedded in the cultural context of the environment. Motivational CQ reflects the capability to direct attention and energy toward learning about and functioning in situations characterized by cultural differences. Those with high motivational CQ direct attention and energy toward cross-cultural situations based on intrinsic interest (Deci \& Ryan, 1985) and confidence in cross-cultural effectiveness (Bandura, 2002). Finally, behavioral CQ reflects the capability to exhibit appropriate verbal and nonverbal actions when interacting with people from different cultures.

\section{Intercultural Communication}

Relationship between communication competence and leadership has been found (Flauto 1999; Rouhiainen 2005). Rouhiainen (2005)has recently studied communication competence of leaders in knowledge based organizations. When such diverse individuals work in a firm to achieve a common goal, it is common that the disputes between personalities occur, causing interpersonal tension, resentment and frustration (Jia-Chi, 2010). Therefore, intercultural communication is particularly important to avoid conflict caused by a diverse cultural working environment. The importance of intercultural communication is not just for the needs of the business world. Almost all areas require intercultural communication skills, especially to be leaders in regional, provincial, especially leaders of a country whose population consists of different cultural backgrounds and different local languages. It is conceivable what will happen if we have leaders who do not possess intercultural communication skills. Conflict will always happen.

Generally, the ability to communicate effectively is undeniably a challenge in the global environment. For an instance, misunderstandings can still arise when both parties speak the same language because of different cultural backgrounds (Hilton, 2007).Intercultural communication occurs when the part involved in the communication activity brings with it a different cultural background, experience and reflects the values held by the group, whether in the form of experience, knowledge, or values as stated by Samovar and Porter (1972) ascited inGudykunst and Young Yun Kim (1984) that intercultural communication is an event that refers to the people involved in it, either directly or indirectly having a different background.

Marquardt and Horvath (2001) argue that, "Leaders around the world are now recognizing the critical importance of global teams as the key to future competitiveness and productivity in today's new networked-style global organization" (p. 3). The need for globally minded and interculturally competent leaders is not only a reality in virtual global teams; it is needed in the multicultural context of regional teams and organizations as well. With the cultures of the world around and within even local expressions of organizations, some authors are beginning to utilize the creative language of "glocalization" to emphasize that global influence is now a local reality (Eoyang, 2005; Roberts, 2007).

According to Chen and Starosta (1996), intercultural communication competence is an umbrella concept that consists of a person's cognitive, affective, and behavioral abilities in the process of intercultural communication. Intercultural sensitivity is the affective aspect of intercultural communication competence, referring to "an individual's ability to develop a positive emotion towards understanding and appreciating cultural differences that promotes appropriate and effective behavior in intercultural communication" (Chen \& Starosta, 1997).Intercultural sensitivity may be understood as the ability to discriminate and experience relevant cultural differences. Related to this, intercultural competence may be understood as the ability to think and act in interculturally appropriate ways (Hammer, et.al., 2003). Increased cultural diversity in different settings calls for abilities to adapt to the unfamiliar environment and to learn to work and live productively with people from different cultural backgrounds, which highlights the ability of intercultural sensitivity (Chen \& Starosta, 1997). 


\section{Global Leaders}

In pursuit of leadership effectiveness in today's globalized world, cross-cultural leaders need to be able to manage culturally diverse settings efficiently, known as a capability of cultural intelligence or cultural quotient CQ (Rockstuhl et al., 2011). Since CQ is significantly related to individual international experiences (Lovvorn \& Chen, 2011), global leaders should be aware and appreciate the diversity they face in leadership practices. It is important to acknowledge that competent leadership has been argued to stem from communication competence of the leaders (Barge 1994; Flauto 1999). Therefore, communication competence becomes a prerequisite for competent leadership (Flauto 1999). In the 21 st century, with the advent of globalization, being able to negotiate effectively across cultures is a crucial aspect of many inter-organizational relationships, including strategic alliances, joint ventures, mergers and acquisitions, licensing and distribution agreements, and sales of products and services (Adler, 2002).Adler and Bartholomew (1992) contend that global leaders need to develop five cross-cultural competence which include understanding business, political, cultural environments worldwide,have a willingness to learn technologies of many other cultures, able to work simultaneously with people from many cultures, able to adapt to living and communicating in other cultures, and have to relate to people from other cultures. This can be seen in the following figure.

\section{Figure 2Five Cross Cultural Competencies for Leaders}

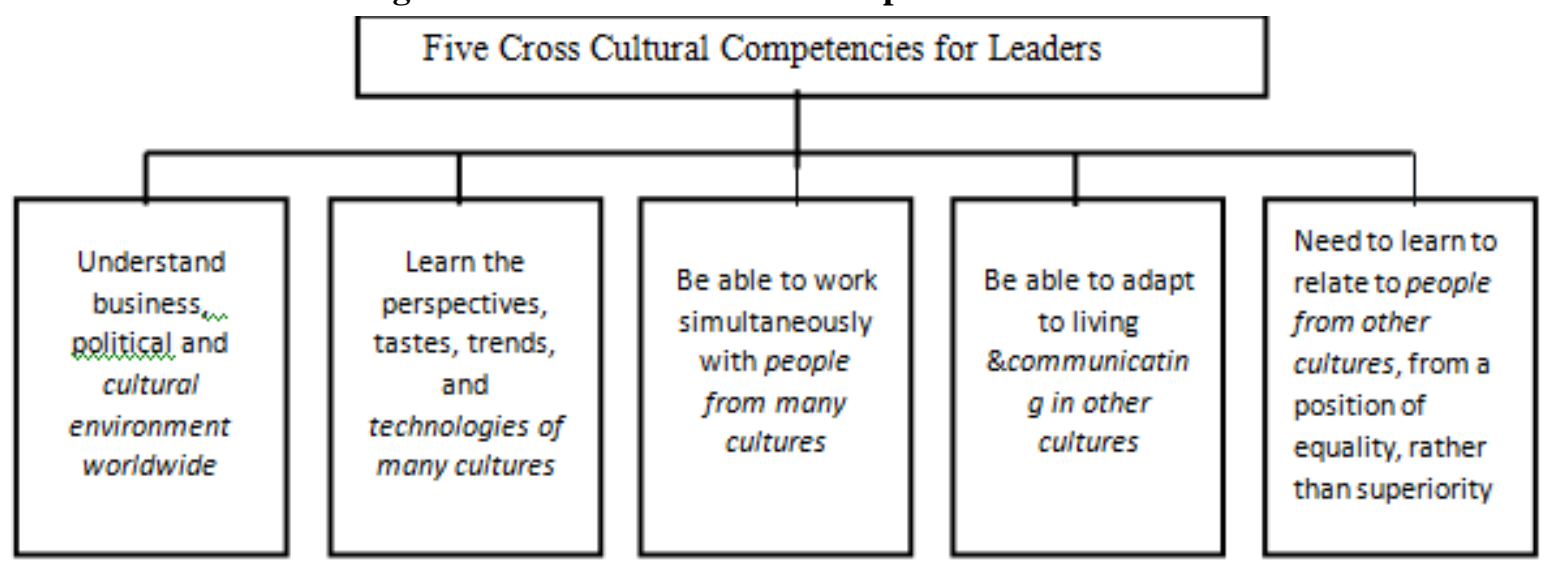

Source -Adler and Bartholomew (1992)

The literature recognizes the crucial role of leadership in the multicultural environment of global business (House et al. 2004; Karpin 1995; Sinclair \& Wilson 2002). It also argues that new skills are required from today's leaders working in the global economy, because leadership itself became more multicultural (Sinclair \& Wilson 2002) and it could be now defined as 'influence across national and cultural boundaries' (Mobley \& Dorfman 2003: xiii).

Therefore, leaders should develop their intercultural communication competence, which can be broadly defined as involving 'knowledge, motivation and skills to interact effectively and appropriately with members of different cultures' (Hammer, et al., 2003: 192). Global leaders need to build their interpersonal skills to deal with racial conflicts that have occured to develop individuals and groups in the workplace (Byrd, 2007). To create a leadership that lasts over time, global leaders must show expected competence in cross-cultural awareness and practice. It is important they understand the significance of leadership and leadership expectations, and to develop and sustain effective leadership strategies for long-term change (Ulrich \& Smallwood, 2012).

In addition to high levels of intellectual intelligence (IQ), and emotional intelligence (EQ), twenty-first century leaders also need cultural intelligence (CQ) to navigate the unique complexity of a global environment (Chin and Gaynier, 2006). This includes the ability to understand key cultural norms of a counterpart's culture; to be ready to listen, observe, and alter one's behavior or communication preferences; and to be open and flexible to reflect and change interaction strategies and expectations depending on the situation and the context (Earley, 2002; Earley \& Ang, 2003; $\mathrm{Ng}$, Van Dyne, \& Ang, 2009a, 2009b). If a person possesses intercultural competence, he will be open minded and tolerates different cultures and positively accepts culture that is different from their own. Such a person takes an active role in an unfamiliar environment that may be in conflict with a personal sense of the best practice or etiquette (Bennett, 1993; Kelly \& Mayers, 1995; Wiseman, et.al., 1989). Earley and Ang (2003) also state that leaders with high $\mathrm{CQ}$ are able to adapt to new global environments as well a s effectively interact with people of diverse cultures. Global leaders also have to possess empathy. Empathy as stated by Goldsmith and Walt (1999)and Goleman (1998 and 2000) leads to cross-cultural sensitivity, and expertise in hiring, building, motivating and retaining talent in different cultures. Chin and Gaynier (2006) modified Hollander's approach (1978), depicting the Leaders-Followers-Situation 
dynamic, by introducing task, relationship and the three intelligences, IQ, EQ and CQ. Chin and Gaynier (2006) states obviously that IQ, EQ and CQ are the triumvirate of leadership competence in the 21st century.

\section{Research Methods}

In this research, a qualitative research method is applied. According to Patton (1990) as quoted in Crabtree \& Miller (1992,p.19) the purpose of qualitative research is not formulating general statements but exploring specific social contexts to achieve better understanding of specified social settings. That is why the qualitative sample is selected purposively. The types of data required in this study include primary data and secondary data. The data were collected by interviewand documentation techniques. This study employed semi-structured interviews, because it can direct the interview more closely, to have a pre-determined set of questions while simultaneously allowing the interviewees sufficient flexibility to shape the flow of information given (Wilkinson and Birmingham, 2003). Robson (2002) also says that it is appropriate to use the interview when the individual perceptions of processes within a social unit are to be studied and the interviewer can ask more questions, if the answer does not come up to expectations.

In this study, a phenomenological approach is employed. Phenomenology is an approach to qualitative research that focuses on the commonality of a lived experience within a particular group. The fundamental goal of the approach is to arrive at a description of the nature of the particular phenomenon (Creswell, 2013).According to Creswell (2007), a phenomenological study "describes the meaning for several individuals of their lived experiences of a concept or a phenomenon" (p. 57). ... When the research problem is to understand the common experiences of several individuals about a phenomenon, a phenomenological study is appropriate. Therefore, this study uses a phenomenological approach since it explores the experiences of the participants.

Data analysis technique used in this research is qualitative analysis technique. The process of data analysis begins by reviewing all data that has been obtained from various sources. Then data reduction was done by making the abstraction. The next step is to organize the data in units. The units were then categorized in the next step. Categorization was done while making coding. The last stage was to check the validity of the data. After this stage was completed, then interpretation of data was done, so that the stages in qualitative data analysis include: data unit processing, data reduction, categorization of data including checking the validity of data, and interpretation of data (Moleong, 2008).

The participants for in depth interview consists of 17 people namely 5 students who have joined student organizations and any other communities, 5 students who have never joined any student organizations to gain information about their knowledge on intercultural communication and global leaders, 2 leaders of student organizationsto dig deeper their perspectives on the criteria of global leaders and what they know about intercultural communication. The interviews were also conducted to 4university graduates who have been working in public and private sector to gain information on their perspectives towards the competence of university graduates in intercultural communication and the demand to be global leaders. Finally, an official of the Ministry of Research, Technology and Higher Education was interviewed to get the perspectives on the ideal 21 st century leaders and what the universities should do to achieve it.

\section{Research Findings and Discussion}

The data obtained from this study show that not all students both from public and private universities understand the importance of intercultural communication for a leader. In general, students who have never joined any organization do not understand about intercultural communication.Of the 10 students interviewed, only 5 said that students must have intercultural communication skills in order to become global leaders. They are students who are members of organizations and are accustomed to leading members with diverse backgrounds while the other 5 students who have never joined a student organization do not really consider intercultural communication as something important for each individual. They tend to say that to be a 21 st century leader requires creativity and mastery of technology.

If a leader does not keep up with the times, he will run out of time, but only thosewith organizational experiences who say that a global leader should not only be seen from the ability of his hard skills but also his soft skills in order to become a leader who is open minded so that there is no more discrimination towards certain ethnics and religion. An open minded leader is a leader who is tolerant and can accept the differences. Global leaders are not only demanded to possess the CQ (Cultural Quotient) so that they can adapt with the new global environment. All the three specifically IQ, EQ and CQ are the main requirements of the global leaders.

From the data obtained even shows that in general university studentswithout organizational experiences still do not understand what is meant by Intercultural Communication. It can be seen from the way they speak, and how they solve problems. They also said that they had never been taught about Intercultural Communication specifically except students studying at the communication science. 
When asked whether there was a student exchange program on campus, all students with no organizational experiences said that there were student exchange programs but lacked socialization so that they still did not see the benefits of taking a student exchange abroad.They also said that there is a Student Executive Board which has a lot of nonacademic programs. However there is no mandatory from the university to opt one of those. So, it depends on the student himself whether he wants to involve or not.

However, the other 5 students with organizational experiences and actively involve in non-academic activities said that having a competence in intercultural communication is really an added value for them. We have got more opportunity compared to those who are not really active in a non-academic program. We have great experiences in joiningthe student exchange and overseas cultural performance that make us become more open minded, more tolerant and able to appreciate the differences. We also can build networks with youths all over the world and we've got opportunity to take internship in multinational companies and international organizations.

While the interview with 4 university graduates proves that intercultural competence must be owned by all university graduates who later will not only become ordinary employees but become leaders since they have to manage people from different cultural background.Nowadays, many leaders do not have empathy and do not appreciate other people. If a leader possesses empathy, he will have a cultural sensitivity and will not do things which hurt other people. This conforms the statement of Goldsmith and Walt (1999) Goleman (1998 and 2000) who say that empathy leads to crosscultural sensitivity, and expertise in hiring, building, motivating and retaining talents in different cultures. All university graduates both working in government institutions and private companies said that global leaders are not only demanded to possess Intelligence Quotient and Emotional Quotient, but also CQ (Cultural Quotient) so that they can adapt with the new global environment. All the three specifically IQ, EQ and CQ are the main requirements of the global leaders.Intercultural communication competence must be owned by all individuals, especially college and university students because when they enter the real world of work, they will face many people from different background. Leaders who have a cultural quotient (CQ) have the ability to communicate with many people because they value the diversity, more tolerant, and have high empathy.

From the interviews conducted, it was found that currently we are lack of broad-minded, tolerant and respectful leaders of differences that can resolve conflicts with the right approach. This is the absolute requirement that leaders must have in the global era. "If we want to create qualified leaders, it is the time for universities and youth organizations to equip the students and cadres with intercultural communication. Global leaders should possess awareness, understanding, appreciation, acceptance, and also adaptation. Even today, all universities not only faculty of communication but also other faculties should teach this subject because all the youths will be our future leaders. Today, we can not rely only on the IQ and EQ. In the 21st century everyone must have CQ in order to build networking, negotiate, managing conflicts well, especially our country, Indonesia consists of diverse ethnics, cultures and religions and we also have to build networking with people around the world. If students have high competence on Intercultural Communication, they can be successful leaders in the future."

Efforts should be done to improve the quality of global leaders. There are now a lot of companies provide intercultural communication training to its top management, especially multinational companies since they want to improve the soft skills of the top leaders. The subjects given also very up to date such as Assertive Leadership, Public Speaking, Conflict Management, Service Excellence and also Intercultural Communication. All of those are needed by leaders in the $21^{\text {st }}$ century. However, the most important thing is that the competence of Intercultural Communication cannot be gained only through training but all of them must understand that it will be obtained through a process.

From the analysis conducted, the results obtained that the factors must be owned by leaders in the current global era is not only havinggood educational background and familiar with current technological developments but also must be open minded so that there is no more discrimination towards certain ethnics and religion. An open minded leader is a leader who is tolerant and can accept the differences. This conforms the statement of Bennet (1993), Kelly \& Mayers (1995), Wiseman, Hammer \& Nishida (1998) who say that an open-minded person tolerates different cultures and positively accepts culture that is different from their own. Such a person takes an active role in an unfamiliar environment that may be in conflict with a personal sense of the best practice or etiquette. In line with the development, global leaders are not only demanded to possess Intelligence Quotient and Emotional Quotient, but also must possess CQ ( Cultural Quotient) so that they can adapt with the new global environment. This conforms the statement of Earley and Ang (2003) who say that leaders with high CQ are able to adapt to new global environments as well a s effectively interact with people of diverse cultures. Also the statement of Chen Oi Chinand Lisa P. Gaynier (2006) saying that IQ, EQ and CQ are the triumvirate of leadership competence in the 21 st century.

In addition we are currently lacking leaders who are knowledgeable, tolerant and able to respect differences so as to resolve conflicts that occur with the right approach. 
This is the absolute requirement that leaders must have in the global era. This is in line with the statements of Goldsmith and Walt (1999) saying that $21^{\text {st }}$ century leaders "must have" characteristic of global leaders, and in line with the opinion of Bennett (1993), Kelly \& Mayers (1995), Wiseman, et al. (1989) who say that an open-minded person tolerates different cultures and positively accepts cultures that are different from their own. Such a person takes an active role in an unfamiliar environment that may be in conflict.

Factors should be possessed by university students and graduates to help improve their leadership competence are awareness, understanding, appreciation, acceptance, and also adaptation. This conforms the statement of Chin, C., Gaynier, L (2006) stating about the Global Leadership Competency Model : Ignorance, Awareness, Understanding, Appreciation, Acceptance, Internalisation, and Adaptation. All universities not only faculty of communication but also other faculties should teach this subject because all youths will be our future leaders. "Today, we can't rely only on the IQand EQ. In the 21st century everyone must have CQ in order to build networking, negotiate, managing conflicts well, and finally he can be a successful leader." This is in line with the statement of Chen Oi Chinand Lisa P. Gaynier (2006)who state that IQ, EQ and CQ are the triumvirate of leadership competence in the 21 st century.

An interview with an official of the Ministry of Research, Technology and Higher Education found the fact that the subject of Intercultural Communication for university students has already been instructed in the National Education System Act No. 20/2003 on Character Building. Character is a person's skills in dealing with others (inter-personal skills) and self-regulating skills (intra-personal skills) that are able to develop a person's performance optimally.

In the university itself, the soft skills related to Intercultural Communication should have been implemented in various non-academic student activities, but unfortunately there are still many universities that still focus only on student academic achievement so that soft skills are not developed well. There are a lot of graduates who fail in the job interview because lack of soft skills not the hard skills.

When asked about how the Ministry conducts the monitoring and evaluation to higher education institutions, he said that it can be done through various competitions and championships for students in which the non-academic achievement that universities implement can be measured.

\section{Conclusion}

From the findings described above, it is seen that there are still many university students who have not understood the importance of Intercultural Communication Competence for the 21st century leaders, except those with organizational experiences and non-academic activities.In addition, up to the present time, we are currently lacking leaders who are knowledgeable, tolerant and able to respect differences so as to resolve conflicts that occur with the right approach. Therefore, efforts should be made to improve the intercultural communication competence of university students so that the quality of future leaders will be better. Universities as educational institutions should focus not only in student academic achievement but also non-academic achievement which can support the improvement of the intercultural communication competence. For future research, the researchers recommend to dig deeper the issues on the model of the implementation of Intercultural Communication in universities with different approaches to be adopted.

\section{References}

Ackerman's, Philip. L. (1996).A theory of adult intellectual development: Process, personality, interests, and knowledge, Intelligence, Volume 22, Issue 2, March-April 1996, Pages 227-257.

Adler, Nancy, J. (2002). Global Companies, Global Society .There Is a Better Way. Journal of Management Inquiry.First Published September 1, 2002 Research Article

Adler, N. J., and Bartholomew, S. (1992), 'Managing globally competent people', Academy of Management Executive, 6, pp. 52-65.

Alnashi, Samah. (2012).An Intercultural competence study of conflict management style amongst managers in crosscultural American organizations.University of Gothenburg, Department of Applied Information Technology Gothenburg, Sweden, May 2012.

Bandura, A. (2002). Environmental sustainability by sociocognitive deceleration of population growth. In P. Schmuck, \& W. Schultz (Eds.). The psychology of sustainable.

Barge KJ (1994). Leadership communication skills for organizations and groups, St. Martin' s Press, New York.P. 21. 
Bennett, Nathan, Blum, Terry,C., Long, Rebecca, G. (1993). A Firm-Level Analysis of Employee Attrition.Sage Journal.Group and Organization Management.First Published December 1, 1993 Research Article. https://doi.org/10.1177/1059601193184006

Bhawuk, D. P. S., \& Brislin, R. W. (1992). The measurement of intercultural sensitivity using the concepts of individualism and collectivism. International Journal of Intercultural Relations, 16, 413-436.

Byrd, M. (2007). Educating and developing leaders of racially diverse organizations. Human Resource Development Quarterly, 18(2), 275-279. doi: 10.1002/hrdq.1203

Ceci, Stephen.J. (1996).A Biological Treatise on Intellectual Development, Expanded Edition. On Intelligence. ISBN 9780674634565, Harvard University Press.

Chen G-M. (2005).A Model of global communication competence. China Media Research 1(1): 3-11.

Chen G-M \& Starosta WJ. (1996). Intercultural communication competence: a synthesis, in Burleson BR \& Kunkel AW (Eds.) Communication Yearbook 19, Sage Publications, Thousand Oaks, CA.

Chen, G. M., \&Starosta, W. J. (1997).A review of the concept of intercultural sensitivity. Human Communication, 1, 116.

Chin, C., Gaynier, L. (2006). Global Leadership Competence: A Cultural Intelligence Perspective. Presented at the 2006MBAAConference.Availablefrom https://www.csuohio.edu/sciences/dept/ psychology/graduate/ diversity/ GlobalLeadership\%201120 6.pdf.

Crabtree, B.F. \& W. L. Miller. 1992. A template approach to text analysis: Developing and using codebooks. Doing Qualitative Research.

Creswell, J. . (2007). Qualitative Inquiry \& Research Design: Choosing Among. Five Approaches, 2 nd ed. California : Sage Publication.

Creswell, J.W. (2013) Research Design Qualitative, Quantitative, and Mixed Methods Approaches. 4th Edition, SAGE Publications, Inc., London.

Deci, E. L., \& Ryan, R. M. (1985). Intrinsic motivation and self-determination in human behavior. New York: Plenum.

Earley, P. C., \& Ang, S. (2003). Cultural intelligence: Individual interactions across cultures. Palo Atlo, CA: Standford University Press.

Earley, P.C. (2002) Redefining interactions across cultures and organizations: Moving forward with cultural intelligence. In B.M. Staw\& R.M. Kramer (Eds.), Research In Organizational Behavior, Vol. 24 (pp. 271299). New York: JAI.

Eoyang, E. C. (2005). Two-way mirrors: Cross-cultural studies in glocalization. Lanham, MD: Lexington Books

Flauto FJ. (1999). Walking the talk: the relationship between leadership and communication competence, The Journal of Leadership Studies 6(1/2): 86-97.

Goldsmith, M. and Walt, K. (1999), "New competencies for tomorrow's global leader", CMA Management, December/January, pp. 20-4.

Goleman, D. (1998), “What makes a leader”, Harvard Business Review, Vol. 76 No. 6, pp. 93-103.

Goleman, D. (2000). 'Leadership that gets results', Harvard Business Review, Vol. 78, no. 2, pp. 78-90

Gudykunst, William B., and Young Yun Kim. (1984). Communicating with strangers: an approach to intercultural communication. New York: Random House.

Hammer, M. R., M. J. Bennett, \& Wiseman R. (2003). Measuring intercultural sensitivity: The intercultural development inventory. International Journal of Intercultural Relations, 27, 421-443.

Hilton, G. (2007). Becoming culturally fluent. Communication World, 24(6), 34.

House R.J. et al. (eds.), (2004). Culture, Leadership, and Organizations: The GLOBE Study of 62 Societies. Thousand Oaks, CA: Sage, 2004.

Jia-Chi, H. (2010). Unbundling task conflict and relationship conflict. International Journal of Conflict Management, 21(3), 334-355. doi: http://dx.doi.org/ 10.1108/10444061011063207 15.

Karpin D.(1995).Report of the industry task force on leadership and management skills, Canberra: Commonwealth of Australia.

Kawar, Tagreed Issa (2012). Cross-cultural Differences in Management. International Journal of Business and Social Science. Vol. 3 No. 6; [Special Issue -March 2012].

Kelley, C. and Meyers, J. (1995), The Cross-Cultural Adaptability Inventory .Minneapolis, MN: National Computer System.

Lovvorn, A.S. \& Chen, J. S. (2011). Developing a global mindset: The relationship between and international assignment and cultural intelligence. International Journal of Business and Social Science, 2(9), 275-283.

Marquardt, M. J., \& Horvath, L. (2001). Global teams: How top multinationals span boundaries and cultures with high-speed teamwork. Palo Alto, CA: Davies-Black.

Miller, K. (2006). Organizational Communication: Approaches and Processes, 5th edition. Boston, Lyn Uhl. 
Mobley \& Dorfman. (2003). Mobley WH \& Dorfman PW (Eds) (2003) Advances in global leadership, JAI An imprint of Elsevier Science, Kidlington, Oxford.Xiii.

Mohsin, A. (2006). Cross-cultural sensitivities in hospitality: A matter of conflict or understanding. Department of Tourism and Hospitality management, pp.1-10.

Moleong, Lexy, J. (2008).MetodologiPenelitianKualitatif, Bandung: PT RemajaRosdakarya.

Ng, T. F. F., Suedmeyer, W. K., Wheeler, E., Gulland, F. \& Breitbart, M. (2009a). Novel anellovirus discovered from a mortality event of captive California sea lions. J Gen Virol 90, 1256-1261.

Ng, T. F. F., Manire, C., Borrowman, K., Langer, T., Ehrhart, L. \& Breitbart, M. (2009b). Discovery of a novel singlestranded DNA virus from a sea turtle fibropapilloma by using viral metagenomics. J Virol 83, 2500-2509.

Patton, M.Q. (1990). Qualitative evaluation and research methods (2nd ed.). Newbury Park, CA: Sage, 532 pp.

Roberts, B. (2007). Glocalization: How followers of Jesus engage a flat world. Grand Rapids, MI: Zondervan.

Robson, Colin (2002). Real World Research: A Resource for Social Scientists and PractitionerResearchers. Oxford: Blackwell.

Rockstuhl Thomas, Soon Stefan, Van Dyne, Ang Linn, Hubert Annen (2011). Beyond General Intelligence (IQ) and Emotional Intelligence (EQ): The Role of Cultural Intelligence (CQ) on Cross- Border Leadership Effectiveness in a Globalized World. Journal of Social Issues. December 2011. https://doi.org/10.1111/j.1540-4560.2011.01730.x

Rouhiainen 2005) Rouhiainen M (2005) The communication competence of leaders in a knowledge-based organization, Frontiers of E-business Research 1-2: 625-636.

Samovar LA \& Porter RE. (2004).Communication between cultures (5th ed.), Thomson Wadsworth, Belmont, CA.

Samovar LA, Porter RE \& McDaniel ER. (2007).Communication between cultures (6th ed.), Thomson Wadsworth, Belmont, CA.

Sinclair A \& Wilson V. (2002).New faces of leadership, Melbourne University Press, Carlton South.

Sternberg, R. J., \& Detterman, D. K. (Eds.). (1986). What is intelligence? Contemporary viewpoints on its nature and definition. Norwood, NJ: Ablex.

Ulrich, D., \& Smallwood, N. (2012). What is leadership?. In W. H. Mobley, Ying Wang, Ming Li (ed.) Advances in Global Leadership. Advances in Global Leadership, Volume 7, Emerald Group Publishing Limited, pp.9-36. doi:10.1108/S1535-1203(2012)0000007005.

Undang Undang Sistem Pendidikan Nasional Nomor 20/2003. Jakarta : The Ministry of Education and Culture, Republic of Indonesia.

Wiseman, R. L., Hammer, M. R., \& Nishida, H. (1989). Predictors of intercultural communication competence. International Journal of Intercultural Relations, 13, 349-370.

Wilkinson, David \& Birmingham, Peter. (2003). Using Research Instruments: A Guide for Researchers. Routledge Study Guides. ISBN 0415272793.Website :https://doi.org/10.1177/1056492602113008 